\title{
Mapping Quantitative Trait Loci for Resistance to Rice Blast
}

\author{
Y. Jia and G. Liu
}

First author: U.S. Department of Agriculture-Agricultural Research Service (USDA-ARS), Dale Bumpers National Rice Research Center (DB NRRC), Stuttgart, AR 72160; and second author: Rice Research and Extension Center, University of Arkansas, Stuttgart, AR 72160.

Current address of second author: Texas A\&M University System AgriLife Research and Extension Center, 1509 Aggie Drive, Beaumont, TX 77713.

Accepted for publication 20 September 2010.

\begin{abstract}
Jia, Y., and Liu, G. 2011. Mapping quantitative trait loci for resistance to rice blast. Phytopathology 101:176-181.

Quantitative trait loci (QTLs) conferring resistance to rice blast, caused by Magnaporthe oryzae, have been under-explored. In the present study, composite interval mapping was used to identify the QTLs that condition resistance to the 6 out of the 12 common races (IB1, IB45, IB49, IB54, IC17, and ID1) of $M$. oryzae using a recombinant inbred line (RIL) population derived from a cross of the moderately susceptible japonica cultivar Lemont with the moderately resistant indica cultivar Jasmine 85. Disease reactions of $227 \mathrm{~F}_{7}$ RILs were determined using a category scale of ratings from 0 , representing the most resistant, to 5 , representing the most susceptible. A total of nine QTLs responsive to different degrees of phenotypic variation ranging from 5.17 to $26.53 \%$ were mapped on

accounting for 5.17\%; qBLAST8.1 co-segregated with SSR marker RM1148 to IB49 accounting for $6.69 \%, q B L A S T 8.2$ at $0.1 \mathrm{cM}$ to SSR marker RM72 to IC17 on chromosome 8 accounting for $7.22 \%$; qBLAST9.1 at $0.1 \mathrm{cM}$ to SSR marker RM257 to IB54, qBLAST9.2 at $2.1 \mathrm{cM}$ to SSR marker RM108, and $q B L A S T 9.3$ at $0.1 \mathrm{cM}$ to SSR marker RM215 to IC17 on chromosome 9 accounting for 4.64, 7.62, and 4.49\%; qBLAST11 at $2.2 \mathrm{cM}$ to SSR marker RM244 to IB45 and IB54 on chromosome 11 accounting for 26.53 and $19.60 \%$; qBLAST12.1 at $0.3 \mathrm{cM}$ to SSR marker OSM89 to IB1 on chromosome 12 accounting for $5.44 \%$; and $q B L A S T 12.2$ at 0.3 and $0.1 \mathrm{cM}$ to SSR marker OSM 89 to IB49 and ID1 on chromosome 12 accounting for 9.7 and $10.18 \%$ of phenotypic variation, respectively. This study demonstrates the usefulness of tagging blast QTLs using physiological races by composite interval mapping.
\end{abstract} chromosomes $3,8,9,11$, and 12: qBLAST3 at 1.9 centimorgans (cM) to simple sequence repeat (SSR) marker RM282 on chromosome 3 to IB45
Additional keywords: infection type.
Rice (Oryza sativa L.) is one of the most important staple foods in many countries and continued increase in rice production is crucial to meeting the growing demand of rice consumption by the world's population. Rice production, however, has been continuously challenged by rice blast caused by Magnaporthe oryzae B.C. Couch (formerly M. grisea). The disease is managed by the use of genetic resistance in rice cultivars integrated with cultural practices including the use of fungicides. Genetic resistance to blast has been known to be controlled by major genes and quantitative trait loci (QTLs). The major blast resistance $(R)$ genes in rice are effective in preventing infections by the fungus that contain the corresponding avirulence genes (AVR) (34). Over 80 major $R$ genes have been described, 12 of which were cloned for improving blast resistance (20). Because $A V R$ genes are highly unstable, as a result, more virulent races that overcome deployed major $R$ genes have been commonly found in commercial fields $(10,23,47)$. In contrast, minor genes that control partial resistance while operating unknown mechanisms still remain more durable (3). Partial blast resistance has been often referred to as field resistance (13) or slow-blasting and dilatory resistance $(29,41)$. QTL underlying partial resistance has been identified using the standard evaluation system for disease rating, the percentage of diseased leaf area and the area under disease progressive curve, and replicated field experiments $(35,36)$.

Utilization of QTLs has been one of the major emphases in breeding rice for resistance to blast. To date, 35 QTLs have been

Corresponding author: Y. Jia; E-mail address: Yulin.Jia@ars.usda.gov

doi:10.1094/PHYTO-06-10-0151

This article is in the public domain and not copyrightable. It may be freely reprinted with customary crediting of the source. The American Phytopathological Society, 2011. documented, some found near known major $R$ genes in elite indica and japonica rice cultivars $(3,16,35,36)$. Cloning of blast QTLs is important for the development of more effective genetic resistance strategies to control blast using marker assisted selection (MAS). One QTL, pi21, which has been isolated encodes a novel protein with heavy-metal-binding and proline-rich domains but has no similarity to proteins of known function (17).

Classic mapping and cloning QTL have been challenged by the ability to quantify disease reactions reproducibly with reasonable costs of labor, land, and the time required for disease evaluation under field conditions. This is due to the fact that significant variation exists in pathogenicity and composition of blast races among different rice-producing areas. For the past 2 decades, several reports indicate that partial resistance in the field is associated with blast races $(5,25,28,32)$. These partial $R$ genes identified by particular races are Pif (44), pi2l (17), Pbl (15), and Pi34 $(45,46)$. Moreover, the AVR gene AvrPi34 was identified to be responsible for efficacy of the major $R$ gene Pi34 (46). These studies suggest that it is possible to map blast resistant QTLs using pathogenic races. In the United States, 10 common races (IA45, IB1, IB45, IB49, IB54, IC17, ID1, IG1, IE1, and IH1) of M. oryzae were identified in the 1960 s (2) and some of them are still present in contemporary rice fields $(8-10,19,28-30,43)$. Recent race surveys indicate that IB49 and IC17 are the two predominant races in commercial rice fields in the southern United States (8). The major blast resistance genes Pita, Piks/h, and $P i b$ have been deployed to provide stable resistance to these races and can be used to identify QTLs in deployed U.S. cultivars.

One key factor for QTL mapping is to correctly measure phenotypic responses of rice to specific races of the fungus. Under greenhouse conditions, common symptoms of rice blast can range from fully susceptible, light green spreading lesions, often ob- 
served on japonica cultivars, to partially susceptible, dark green lesions with brown margins on indica cultivars that correspond to local induced resistance. These variations can be measured as category data for QTL mapping because they resemble typical blast symptoms observed on rice cultivars with partial resistance.

Jasmine 85, a long-grain indica cultivar initially developed at International Rice Research Institute (IRRI), Philippines, and officially released in 1989 by the USDA-ARS and the Texas Agricultural Experiment Station was adapted to the southern United States and possesses considerable resistance to both blast and sheath blight (30). 'Lemont', a semi-dwarf tropical japonica cultivar commercially grown in the 1980 s and 1990 s was resistant to some blast races in the southern United States (4). Lemont does not exhibit resistance to the races IC17, IB49, and IE1 under greenhouse conditions; however, Lemont does express partial resistance when exposed to these races in the field. A mapping population derived from the cross of Lemont with Jasmine 85 was successfully used to map the resistant QTLs for sheath blight (25). The present study utilizes this mapping population to map the QTLs responsible for blast resistance.

The objectives of this study were to (i) identify genetic factors that confer resistance to six races of blast fungus and (ii) map blast QTL using these physiological races under greenhouse conditions.

\section{MATERIALS AND METHODS}

Plant materials and growth. The recombinant inbred line (RIL) population derived from the cross of Lemont $\times$ Jasmine 85 (hereafter called LJRIL) was developed using single-seed descent in a greenhouse at the USDA-ARS, Dale Bumpers National Rice Research Center, Stuttgart, Arkansas (Y. Jia and G. Liu, unpublished data). This LJRIL population of 256 individuals has been used to map QTLs to rice sheath blight disease (25) and 227 LJRILs of the same population were used to map QTLs to rice blast in this study. A total of 29 RILs were eliminated because of problems in germination and disease evaluation. Rice seedlings were grown using a modified method (19). Specifically, local clay soils from a rice farm were sterilized and used for growing rice plants. Plants were grown in a greenhouse at 24 to $30^{\circ} \mathrm{C}$ with a light and dark cycle of 16 and $8 \mathrm{~h}$, respectively, for 2 weeks, until they were at the four-leaf stage for disease evaluation and DNA preparation.

Race selection, fungal growth, and spore production. Twelve common U.S. races (isolates) of $M$. oryzae, IA45 (75L14), IB1 (isolate unnamed), IB45 (isolate unnamed), IB49 (ZN61), IB54 (isolate unnamed), IB33 (FL9), IC17 (ZN60), IE-1k (TM2), ID1 (ZN42), IE1 (ZN13), IG1 (ZN39), and IH1 (isolate unnamed) (19), from the southern United States were used to evaluate pathogenicity toward Jasmine 85 and Lemont. The races IB1, IB45, IB49, and IC17 with different disease reactions on both parents were used to determine disease reactions in LJRIL populations. Blast races were stored on desiccated filter papers in a freezer at $-20^{\circ} \mathrm{C}$ at the lab of the molecular pathology group of USDAARS, Dale Bumpers National Rice Research Center. Dried filter papers containing fungal mycelia were placed on oatmeal agar plates. The inoculated plates were placed at $24^{\circ} \mathrm{C}$ for 7 days under a light and dark cycle of 16 and $8 \mathrm{~h}$, respectively. Hyphal tips were transferred to oatmeal agar and cultures were incubated for an additional 12 days for producing spores. Spores were har- vested by scraping the plates using a surgical blade in a water solution that contained $0.15 \%$ gelatin, and collected spores were filtered through three layers of cheesecloth and counted. The concentration of the initial conidial suspension was determined using the method described by Sambrook and Russell (33). A conidial suspension was delivered to both chambers of a hemacytometer by capillary action. The numbers of conidia in five of the nine large squares in both chambers were summed and multiplied by 1,000 to give the number of spores per milliliter.

Blast inoculation. Inoculation was modified based on a standard method described by Valent et al. (40). Rice plants were placed in a plastic bag and spores were sprayed with $2 \mathrm{ml}$ of conidial suspension using a Paasche IVL double action airbrush collected with a pressure pump. Seedlings were inoculated in a plastic bag using a spore concentration of 5 to $15 \times 10^{5}$ spores $/ \mathrm{ml}$. Inoculated seedlings were sealed in a bag overnight in a laboratory at $24^{\circ} \mathrm{C}$ to maintain at least $70 \%$ humidity. At $24 \mathrm{~h}$ after incubation, seedlings were removed and returned back to the same greenhouse for an additional 6 days to allow for disease development.

Blast evaluation. Disease reactions were evaluated 1 week after inoculation with the pathogen. The greenhouse-grown rice seedlings at three- to four-leaf stage were used for inoculation. A disease rating system described by Valent et al. (39) was modified to determine the phenotypes of each progeny of the mapping population. The second youngest leaf was evaluated for disease reactions because disease reactions of each leaf at different growth stages were not the same. Disease reaction was evaluated on a scale of 0 to 5 , where 0 indicates no visible lesion, 1 indicates only small point lesions appearing at the sites of infections, 2 indicates lesion sizes smaller than $2 \mathrm{~mm}$ and no visible fungal mass, 3 indicates lesions greater than $2 \mathrm{~mm}$ occupying $10 \%$ or less of the leaf area, 4 indicates lesions greater than $3 \mathrm{~mm}$ occupying more than $10 \%$ and less than $50 \%$ of the leaf area; and 5 indicates lesions greater than $50 \%$ of the leaf area. For parent screening, ratings of 0 to 2 are considered resistant and 3 to 5 are susceptible.

DNA preparation, data analysis, and QTL mapping. DNA was prepared from detached leaves and extracted using a method described by Tai and Tanksley (37). Disease reactions of 5 to 10 plants were evaluated per line and the average of disease scores was used for composite interval mapping (CIM). QTL analysis was performed using the previously constructed simple sequence repeat (SSR) map $(22,25)$ with 199 SSR markers in Windows QTL Cartographer version 2.5 (24). The default CIM control parameters: model 6 of standard model, five control markers, $10 \mathrm{cM}$ of window size, and forward regression method. The LOD threshold of $\geq 2.4$ based on published literatures for sheath blight QTL mapping was used to declare the presence of a putative QTL (25). Additive effect and percentage of variation explained by individual infection category QTL were estimated and named following the gene nomenclature system for rice (31).

\section{RESULTS AND DISCUSSION}

Reactions of the parental rice cultivars and LJRILs to $M$. oryzae races. The results of the greenhouse assays demonstrated that Jasmine 85 and Lemont were resistant to the races IA45, IG1, and IH1, and susceptible to the races IB33, IE1, and IE1k of $M$. oryzae, respectively (Table 1). However, Jasmine 85 was resistant

TABLE 1. Differential responses of the parental rice cultivars Lemont and Jasmine 85 to 12 races of Magnaporthe oryzae ${ }^{\mathrm{a}}$

\begin{tabular}{|c|c|c|c|c|c|c|c|c|c|c|c|c|}
\hline \multirow[b]{2}{*}{ Parent } & \multicolumn{12}{|c|}{ Race of $M$. oryzae } \\
\hline & IA45 & IB1 & IB33 & IB45 & IB49 & IB54 & $\mathrm{IC} 17$ & ID1 & IE1 & IE1K & IG1 & IH1 \\
\hline Lemont & 0 & 4 & 5 & 0 & 4 & 0 & 4 & 5 & 4 & 4 & 1 & 1 \\
\hline Jasmine 85 & 1 & 0 & 4 & 4 & 0 & 3 & 1 & 0 & 4 & 4 & 1 & 1 \\
\hline
\end{tabular}

${ }^{a}$ Experiment was repeated three times independently for each rating in a 0 to 5 scale. 
to the races IB1, IB49, IC17, and ID1, and Lemont was susceptible to these races. Disease reactions of Lemont to IB49, IC17, ID1, and IG1 (4) are consistent with our ratings; however, reaction of Lemont to race IB1 in the present study was rated as 4, which is susceptible, not as previously determined to be resistant to IB1(4). This discrepancy could be due to different isolates of the same race that were used in addition to differences in experimental conditions and rating system. Lemont was found to be resistant to races IB45 and IB54, and Jasmine 85 was susceptible to both of them. Despite race reactions of Jasmine 85 to each race not documented, Jasmine 85 was evaluated as 4 on a scale of 0 to 9 in response to IB54 by Marchetti et al. (30), which is consistent with our score of 3 on a scale of 0 to 5. Disease reaction of Lemont to races IB45, IB543, and IG1 determined by Bollich et al. (4) were the same as the present study. Nevertheless, races
IB1, IB49, IC17, and ID1 of $M$. oryzae can be used to identify resistant factors from Jasmine 85 and races IB45 and IB54 can be used to identify resistance factors from Lemont.

Frequency distribution of disease reactions of the LJRILs to each race is summarized in Figure 1. Disease reactions of most individuals to all races were determined to be infection type 0 , indicating that strong resistant reactions occurred. Few individuals were observed to have infection type 5 to races IB45, IB49, and IC17. However, the fewest individuals were observed to have infection type 1 to the races IB1 and ID1. It is worthy to note that there were a few RILs in which consistent disease reactions were unable to be obtained despite repeated efforts and these RILs were removed for mapping. In the past, we also encountered a similar situation in which disease reactions in a few RILs of another mapping population were difficult to determine (21). One

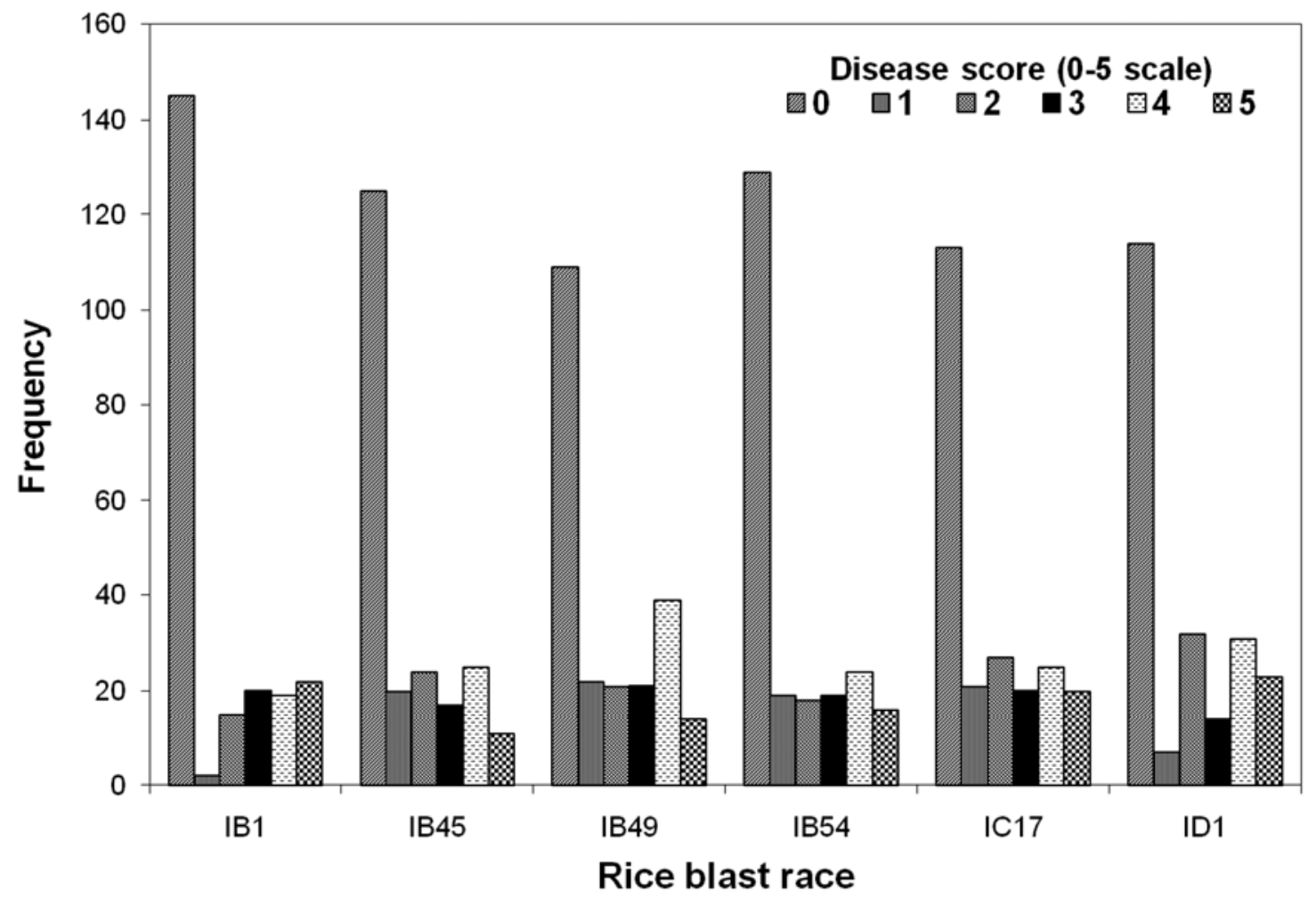

Fig. 1. Frequency distribution of disease reactions of 227 recombinant inbred lines from the cross of Lemont and Jasmine 85 assayed in greenhouse for blast resistance.

TABLE 2. Summary of quantitative trait loci (QTLs) responsible to blast resistance ( $q B L A S T$ ), chromosomal and physical locations, percentage of phenotypic variation, and the known $R$ genes nearby $q B L A S T$ QTLs

\begin{tabular}{|c|c|c|c|c|c|c|c|c|c|}
\hline QTL & $\begin{array}{l}\text { Chromo- } \\
\text { some }\end{array}$ & $\begin{array}{c}\text { Magnaporthe } \\
\text { oryzae race }\end{array}$ & $\begin{array}{l}\text { Marker } \\
\text { interval }\end{array}$ & $\begin{array}{c}\text { Nearest } \\
\text { marker locus }\end{array}$ & $\begin{array}{l}\text { Genetic distance } \\
\text { to } q B L A S T(\mathrm{cM})^{\mathrm{b}}\end{array}$ & $\begin{array}{l}\text { LOD } \\
\text { value }^{\mathrm{c}}\end{array}$ & $\begin{array}{c}\text { Phenotypic } \\
\text { variation (\%) }\end{array}$ & $\mathrm{AE}^{\mathrm{d}}$ & $\begin{array}{c}\text { Known blast } \\
R \text { genes }^{\mathrm{e}}\end{array}$ \\
\hline qBLAST3 & 3 & IB45 & RM251-RM338 & RM282 (12.4) & 1.9 & 3.4 & 5.17 & -0.45 & IE1k resistance \\
\hline qBLAST8.1 & 8 & IB49 & RM6863-RM72 & RM1148 (4.0) & 0.0 & 4.3 & 6.69 & 0.45 & Pi36 (2.0) \\
\hline qBLAST9.1 & 9 & IB54 & RM257-RM108 & RM257 (17.7) & 0.1 & 3.3 & 4.64 & 0.47 & \\
\hline qBLAST9.2 & 9 & IC17 & RM257-RM107 & RM108 (17.9) & 2.1 & 4.3 & 7.62 & 0.52 & NBS-LRR \\
\hline qBLAST9.3 & 9 & IC17 & RM107-RM245 & RM215 (21.2) & 0.1 & 2.9 & 4.49 & 0.42 & \\
\hline qBLAST12.1 & 12 & IB1 & RM6998-OSM89 & OSM89 (7.9) & 0.3 & 3.3 & 5.44 & 0.46 & Pita (10.6) \\
\hline \multirow{2}{*}{$q B L A S T 12.2$} & & IB49 & RM247-RM277 & OSM89 (7.9) & 0.3 & 5.9 & 9.70 & 0.57 & \\
\hline & & ID1 & RM247-RM277 & OSM89 (7.9) & 0.1 & 5.7 & 10.18 & 0.64 & \\
\hline
\end{tabular}

a The numbers in brackets present the physical locations (MB) of the nearest markers on rice chromosomes.

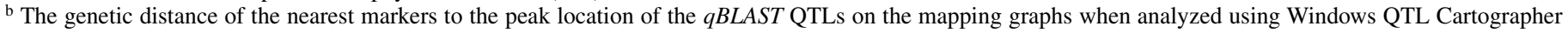
2.5 .

c $q$ BLAST QTLs were declared using the likelihood odds ratio (LOD) value of 2.4.

d AE indicates additive effect, the effect associated with substitution of a Jasmine 85 allele by its corresponding Lemont allele.

e The numbers in brackets present the physical locations (MB) of the known blast $R$ genes on rice chromosomes from the cited references (1,6,12,13). 
of the most likely possibilities is that these RILs were created with random recombination events so that phenotypic response to blast was extremely sensitive to experimental conditions.

Analysis of blast resistant QTLs. A total of nine partial resistance genes were identified using six races of $M$. oryzae. Of them, three QTLs were from Lemont and six from Jasmine 85. The first QTL $q B L A S T 11$ in Lemont was identified on chromosome 11 using IB45 and IB54 (Table 2, Fig. 2). qBLAST11 was mapped between the SSR markers RM206 and RM224, 2.2 cM to RM224 on chromosome 11, accounting for 26.53 and $19.60 \%$ of disease reactions, respectively. Lemont was shown to carry the major blast $R$ genes, Pikm/Pik $(1,11)$ that is located within 0.6 megabases (MB) from the border marker RM224 of $q B L A S T 11$. Hence, more effective blast resistance can be achieved if both $q B L A S T 11$ and Pikm/Pik can be incorporated into advanced breeding lines using MAS. The second QTL qBLAST3 in Lemont was mapped between RM251 and RM338, $1.9 \mathrm{cM}$ to RM282 on chromosome 3 using the race IB45, accounting for $5.17 \%$ of disease reactions. The marker RM282 was previously associated with IE1K resistance (12). IE1 K is a virulent race that overcomes the major blast $R$ gene Pita (20). Despite Lemont being susceptible to IE1K, the discovery of co-segregation of $q B L A S T 3$ with resistance to both IE1K and IB45 suggests that a different RM282 haplotype may be useful to tag resistance to IE1K in additional to IB45. The third QTL qBLAST9.1 in Lemont was mapped between RM257 and
RM108, $0.1 \mathrm{cM}$ to RM257 on chromosome 9 using the races IB54 accounting for $4.64 \%$ of disease reactions. There were no reports of the $R$ genes at the proximal to these mapped QTLs on chromosome 9 .

In Jasmine 85, two QTLs ( $q$ BLAST8.1 and $q B L A S T 12.2)$ were identified using the race IB49, and $q B L A S T 12.2$ was also identified using ID1, three QTLs ( $q$ BLAST8.2, qBLAST9.1, and $q B L A S T 9.2)$ were identified using the race IC17, and one QTL, (qBLAST12.1) was identified using IB1 (Table 2, Fig. 2). qBLAST8.1 was mapped between RM6863 and RM72, co-segregated with RM1148 on chromosome 8; qBLAST8.2 was mapped between RM310 and RM72 to $0.1 \mathrm{cM}$ to the closest marker RM72. Interestingly, it was noticed that a major blast $R$ gene, Pi36, was mapped approximately 2 MB from RM1148 (26). Conceivably, pyramiding both $q B L A S T 8.1$ and Pi36 into advanced breeding lines may achieve more durable resistance to blast. Further study to determine if Jasmine 85 carries Pi36 will support our prediction.

qBLAST9.2 was mapped between RM257 and RM108, $2.1 \mathrm{cM}$ to RM108, and $q B L A S T 9-3$ was mapped between RM107 and RM245, $0.1 \mathrm{cM}$ to RM215 on chromosome 9 accounting for 7.62 and $4.49 \%$ of disease reactions, respectively. The RM108 region harbors several nucleotide binding site leucine-rich repeat (NBSLRR) type genes. These NBS-LRR genes may be $R$ genes to unknown races of the blast pathogen. qBLAST12.1 was mapped

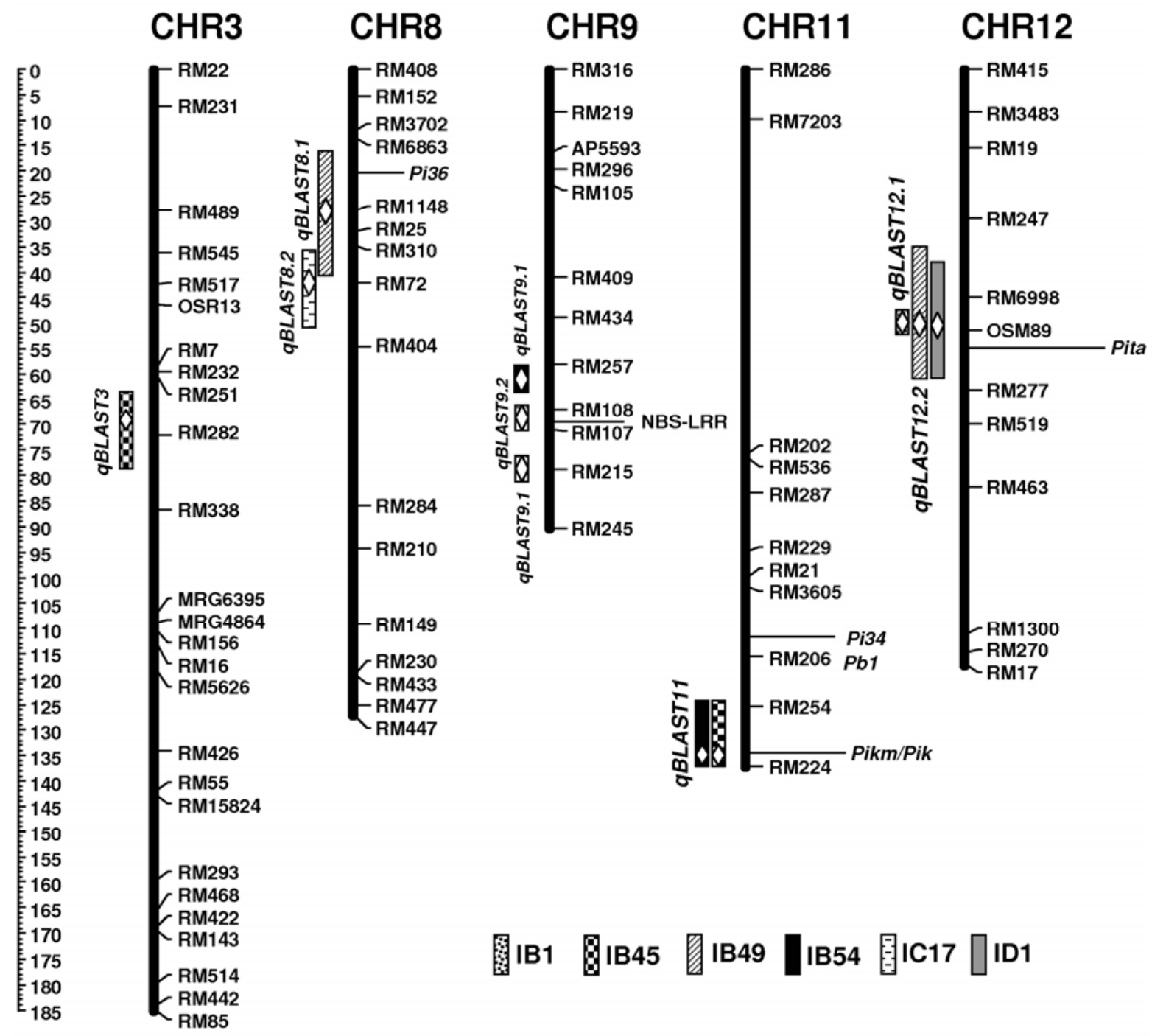

Fig. 2. Chromosomal locations of the blast-quantitative trait loci mapped in this study and estimated locations of the major known blast $R$ genes previously mapped for six races of Magnaporthe oryzae. 
between RM247 and RM277, $0.3 \mathrm{cM}$ to OSM89 on chromosome 12 , accounting for $5.44 \%$ of disease reactions. qBLAST12.2 was mapped between RM247 and RM277, closer to OSM89 accounting for 9.7 and $10.18 \%$ of disease reactions to IB49 and ID1, respectively. The major blast $R$ gene Pita at $10.6 \mathrm{MB}(6,18)$ is linked to the closest marker OSM89 (7.9 MB) (14). It was recently determined that the resistance Pita gene was not present in Jasmine 85 (Y. Jia, unpublished data). Pita has been one of the most effective blast $R$ genes in the southern United States for 2 decades (20). Incorporation of $q B L A S T 12.1$ and $q B L A S T 12.2$ in Pita-containing rice cultivars would reach more durable and effective resistance to rice blast.

Consistent with the results of the present study, a number of investigators reported that partial resistance can be associated with specific races $(5,27,32,38)$. The partial resistance genes Pif was mapped at the similar location of $q B L A S T 11$ on chromosome 11 (44, this study), pi21 on chromosome 4 (17), Pb1 (15) and Pi34 (45,46), qLB11.2 (7) on chromosome 11 near Pik. Thus far, it seems that most blast QTLs were mapped on chromosomal locations near the major blast $R$ genes, which suggests that blast QTL may be conditioned by a major $R$ gene. This hypothesis is not supported by the first cloned partial resistance gene pi 21 that encodes a protein with heavy-metal-binding and proline-rich domains but has no similarity to proteins of known function (17). In contrast, Wang et al. (42) presented data to suggest that major $R$ genes can be involved in partial resistance. Moreover, the $A V R$ gene AVRPi34 was found to determine the efficacy of a partial resistance gene Pi34 (46) suggesting that partial resistance also operates at a gene-for-gene level. Continued fine mapping and cloning of more QTLs should help to better understand molecular mechanisms of partial resistance gene-mediated resistance.

Race-specific resistance to blast has been mapped as dominant $P i$-genes using qualitative data converted from category data. Different types of blast infections in the same qualitative category were not considered for major $R$ gene mapping. Disease reactions scored as 0 to 2 for resistant in a 0 to 5 scale, 0 to 4 for resistant in a 0 to 9 scale were distinct reproducible, whereas 3 to 5 and 5 to 9 for susceptible, respectively, were distinct reproducible. These different infection types, i.e., $0,1,2$ to 9 , resembling different phenotypes observed under field conditions were used for map construction in multiple interval mapping (24).

In summary, a total of nine new QTLs that condition resistance to six races of rice blast were mapped onto different chromosomal locations with easy to use molecular markers using Windows QTL Cartographer (24). These QTLs were identified from adapted indica and japonica cultivars and the RILs with most can be immediately selected and used as breeding parents for improved blast resistance. Furthermore, disease reactions were evaluated using individual races of blast fungus under greenhouse conditions instead of classic field plot experiments whose results are influenced by environmental conditions. Identified molecular markers using phenotypic data obtained from a highly controlled environment should be easily adapted and used for markerassisted breeding.

\section{ACKNOWLEDGMENTS}

We thank M. Lin for assistance in greenhouse evaluation of blast disease reactions; M. H. Jia for assistance in constructing the SSR map; and E. McWhirter, X. G. Zhou (Texas A\&M University System Agrilife Research and Extension Center), and L. Zeng (Department of Biology, University of Arkansas, Little Rock) for critical readings of the manuscript.

\section{LITERATURE CITED}

1. Ashikawa, I., Hayashi, N., Yamane, H., Kanamori, H., Wu, J., Matsumoto, T., Ono, K., and Yano, M. 2008. Two adjacent NBS-LRR class genes are required to confer Pikm-specific rice blast resistance. Genetics 180:22672276 .
2. Atkins, J. G., Robert, A. L., Adair, C. R., Goto, K., Kozaka, T., Yanagida, R., Yamada, M., and Matsumoto, S. 1967. An international set of rice varieties for differentiating races of "Pyricularia oryzae". Phytopathology 57:297-301

3. Ballini, E., Morel, J. B., Droc, G., Price, A., Courtois, B., Notteghem, J. L., and Tharreau, D. 2008. A genome-wide meta-analysis of rice blast resistance genes and quantitative trait loci provides new insights into partial and complete resistance. Mol. Plant-Microbe Interact. 21:859-868.

4. Bollich, C. N., Webb, B. D., Marchetti, M. A., and Scott, J. E. 1985. Registration of 'Lemont' rice. Crop Sci. 25:883-885.

5. Bonman, J. M., Bandong, J. M., Lee, Y. H., and Lee, E. J. 1989. Race specific partial resistance to blast in temperate japonica rice cultivars. Plant Dis. 73:496-499.

6. Bryan, G.-T., Wu, K., Farrall, L., Jia, Y., Hershey, H. P., McAdams, S. A., Faulk, K. N., Donaldson, G. K., Tarchini, R., and Valent, B. 2000. A single amino acid difference distinguishes resistant and susceptible alleles of the rice blast resistance gene Pi-ta. Plant Cell 12:2033-2045.

7. Cho, Y.-C., Kwon, S.-W., Suh, J.-P., Kim, J.-J., Lee, J.-H., Roh, J.-H., Oh, M.-K., Kim, M.-K., Ahn, S.-N., Koh, H.-J., Yang, S.-J., and Kim, Y.-G. 2008. QTL identification and confirmation of field resistance to leaf blast in temperate japonica rice (Oryza sativa L.). J. Crop Sci. Biotechnol. 11:269-276.

8. Correll, J. C., Boza, E. J., Seyran, E., Cartwright, R. D., Jia, Y., and Lee, F. N. 2009. Examination of the rice blast pathogen population diversity in Arkansas, USA-Stable or Unstable? Pages 217-228 in: Advances in Genetics, Genomics and control of rice blast disease. G.-L. Wang and B. Valent, eds. Springer Science and Businesses Media B.V., New York.

9. Correll, J. C., Harp, T. L., Guerber, J. C., Zeigler, R. S., Liu, B., Cartwright, R. D., and Lee, F. N. 2000. Characterization of Pyricularia grisea in the United States using independent genetic and molecular markers. Phytopathology 90:1396-1404.

10. Correll, J. C., and Lee, F. N. 2000. Relationship of races, DNA fingerprint groups, vegetative compatibility groups, and mating type among isolates of rice blast pathogen Pyricularia grisea in Arkansas. Pages 189-200 in: B. R. Wells Rice Research Studies 1999. R. J. Norman and C. A. Beyrouty, eds. University of Arkansas Agricultural Experiment Station Research Series 476.

11. Costanzo, S., and Jia, Y. 2010. Sequence variation at the rice blast resistance gene $P i-k m$ locus: Implications for the development of allele specific markers. Plant Sci. 178:523-530.

12. Eizenga, G. C., Agrama, H. A., Lee, F. N., and Jia, Y. 2006. Identifying novel resistance genes in newly introduced blast resistant rice germplasm. Crop Sci. 46:1870-1878.

13. Ezuka, A. 1972. Field resistance of rice varieties to rice blast. Rev. Plant Prot. Res. 5:1-21.

14. Fjellstrom, R., Conaway-Bormans, C. A., McClung, A., Marchetti, M. A., Shank, A. R., and Park, W. D. 2004. Development of DNA markers suitable for marker assisted selection of three $P i$-genes conferring resistance to multiple Pyricularia grisea pathotypes. Crop Sci. 44:17901798.

15. Fujii, K., Hayano-Saito, Y., Shumiya, A., and Inoue, M. 1995. Genetical mapping based on the RFLP analysis for the panicle blast resistance derived from a rice parental line St. No. 1. Breed. Sci. 45:209. (In Japanese)

16. Fukuoka, S., and Okuno, K. 1997. QTL analysis for field resistance to rice blast using RFLP markers. Rice Genet. Newsl. 14:99.

17. Fukuoka, S., Saka, N., Koga, H., Ono, K., Shimizu, T., Ebana, K., Hayashi, N., Takahashi, A., Hirochika, H., Okuno, K., and Yano, M. 2009. Loss of function of a proline-containing protein confers durable disease resistance in rice. Science 325:998-1001.

18. Jia, Y. 2009. Artificial introgression of a large chromosome fragment around the rice blast resistance gene Pi-ta in backcross progeny and several elite rice cultivars. Heredity 103:333-339.

19. Jia, Y., Lee, F., and McClung, A. 2009. Determination of resistance spectra to U.S. races of Magnaporthe oryzae causing blast in a recombinant inbred line population. Plant Dis. 93:639-644.

20. Jia, Y., Liu, G., Costanzo, S., Lee, S., and Dai, Y. 2009. Current progress on genetic interactions of rice with rice blast and sheath blight fungi. Front. Agric. China 3:231-239.

21. Jia, Y., and Moldenhauer, K. A. K. 2010. Development of monogenic and digenic rice lines for blast resistance genes $\mathrm{Pi}$-ta, Pi-kh/Pi-ks. J. Plant Registration 4:163-166.

22. Kosambi, D. D. 1944. The estimation of map distances from recombination values. Ann. Eugen. 12:172-175.

23. Lee, F. N., Cartwright. R. D., Jia, Y., and Correll, J. C. 2009. Field resistance expressed when the Pi-ta gene is compromised by Magnaporthe oryzae. Pages 281-289 in: Advances in Genetics, Genomics and Control of Rice Blast Disease. G.-L. Wang and B. Valent, eds. Springer Science and Businesses Media B.V., New York.

24. Li, J., Wang, S., and Zeng, Z.-B. 2006. Multiple-interval mapping for 
ordinal traits. Genetics 173:1649-1663.

25. Liu, G., Jia, Y., Correa-Victoria, F., Prado, G. A., Yeater, K. M., McClung, A. M., and Correll, J. C. 2009. Mapping quantitative trait loci responsible for resistance to sheath blight in rice. Phytopathology 99:1078-1084.

26. Liu, X., Lin, F., Wang, L., and Pan, Q. 2007. The in silico map-based cloning of Pi36, a rice CC-NBS-LRR gene which confers race-specific resistance to the blast fungus. Genetics 176:2541-2549.

27. Lopez-Gerena, J. 2006. Mapping QTL controlling durable resistance to rice blast in the cultivar Oryzica Llanos 5. Ph.D. thesis, Universidad del Valle, Plant Pathology College of Agriculture, Cali, Colombia and Kansas State University, Manhattan, KS.

28. Marchetti, M. A. 1994. Race-specific and rate-reducing resistance to rice blast in U.S. cultivars. Pages 231-244 in: Rice Blast Disease. R. S. Zeigler, S. Leong, and P. S. Teng, eds. Commonw. Agric. Bur. Int. Wallingford, UK

29. Marchetti, M. A. 1983. Dilatory resistance to rice blast in USA rice. Phytopathology 73:645-649.

30. Marchetti, M. A., Bollich, C. N., Webb, B. D., Jackson, B. R., McClung, A. M., Scott, J. E., and Hung, H. H. 1998. Registration of 'Jasmine 85' rice. Crop Sci. 38:896.

31. McCouch, S. R. 2008. Gene nomenclature system for rice. Rice 1:72-84.

32. Roumen, E. C. 1992. Small differential interactions for partial resistance in rice cultivars to virulent isolates of the blast pathogen. Euphytica 64:143-148.

33. Sambrook, J., and Russell, D. W., eds. 2001. Estimation of cell number. A8.6 in: Molecular Cloning: A Laboratory Manual, Vol. 3. Cold Spring Harbor Laboratory, Cold Spring Harbor, NY.

34. Silue, D., Nottenghem, J. L., and Tharreau, D. 1992. Evidence for a genefor-gene relationship in the Oryza sativa-Magnaporthe grisea pathosystem. Phytopathology 82:577-580.

35. Tabien, R. E., Li, Z., Paterson, A. H., Marchetti, M. A., Stansel, J. W., and Pinson, S. R. M. 2002. Mapping QTL for field resistance to the rice blast pathogen and evaluating their individual and combined utility in improved varieties. Theor. Appl. Genet. 105:313-324.

36. Tabien, R. E., Li., Z., Paterson, A. H., Marchetti, M. A., Stansel, J. W., Pinson, S. R. M., and Park, W. D. 2000. Mapping of four major rice blast resistance genes from 'Lemont' and 'Teqing', and evaluation of their combinatorial effect for field resistance. Theor. Appl. Genet. 101:12151225.

37. Tai, T., and Tanksley, S. D. 1990. A rapid and inexpensive method for isolation of total DNA from dehydrated plant tissue. Plant Mol. Biol. Rep. 8:297-303.

38. Talukder, Z. I., Tharreau, D., and Price, A. H. 2004. Quantitative trait loci analysis suggests that partial resistance to rice blast is mostly determined by race-specific interactions. New Phytol. 162:197-209.

39. Valent, B. 1997. The rice blast fungus, Magnaporthe grisea. Plant relationships. Pages 37-54 in: The Mycota V Part. B. G. C. Carroll and P. Tudzynoski. eds. Springer-Verlag, Berlin, Heidelberg.

40. Valent, B., Farrall, L., and Chumley, F. G. 1991. Magnaporthe grisea genes for pathogenicity and virulence identified through a series of backcrosses. Genetics 127:87-101.

41. Villareal, R. L., Nelson, R. R., Mackenzie, D. R., and Coffman, W. R. 1981. Some components of slow-blasting resistance in rice. Phytopathology 71:608-611.

42. Wang, G.-L., Mackill, D. J., Bonman, J. M., McCouch, S. R., Champoux, M. C., and Nelson, R. J. 1993. RFLP mapping of genes conferring complete and partial resistance to blast in a durably resistant rice cultivar. Genetics 136:1421-1434.

43. Xia, J. Q., Correll, J. C., Lee, F. N., Ross, W. J., and Rhoads, D. D. 2000 Regional population diversity of Pyricularia grisea in Arkansas and the influence of host selections. Plant Dis. 84:877-884.

44. Yunoki, T., Ezuka, A., Sakurai, Y., Shinoda, H., and Toriyama, K. 1970. Studies on the varietal resistance to rice blast. 3. Testing methods for field resistance on young seedling grown in greenhouse. Bull. Chugoku Natl. Agric. Exp. Stn. E6:1-19.

45. Zenbayashi, K., Ashizawa, T., Tani, T., and Koizumi, S. 2002. Mapping of the QTL (quantitative trait locus) conferring partial resistance to leaf blast in rice cultivar Chubu 32. Theor. Appl. Genet. 104:547-552.

46. Zenbayashi-Sawata, K., Ashizawa, T., and Koizumi, S. 2005. Pi34AVRPi34: A new gene-for-gene interaction for partial resistance in rice to blast caused by Magnaporthe grisea. J. Gen. Plant Pathol. 71:395-401.

47. Zhou, E., Jia, Y., Correll, J., and Lee, F. N. 2007. Instability of the Magnaporthe oryzae avirulence gene AVR-Pita alters virulence. Fungal Genet. Biol. 44:1024-1034. 